\title{
Promoting interdisciplinary approaches to solving the complexity of environmental problems in Indonesia
}

\author{
Kathryn A. Monk \\ Biosciences Department, Swansea University \\ Singleton Park, Sketty, Swansea SA2 8PP, United Kingdom \\ Corresponding author: kathryn.monk@swansea.ac.uk
}

\section{INTRODUGTION}

As an ecologist, I believe we are now seeing the maturing of what we could call the Age of Ecology. An Age in which we finally develop that coherent and essential mainstream narrative for our future; one in which we tackle the interdependencies of nature loss, the climate emergency, and unsustainable production and consumption.

The challenge has always been to recognise that the world is our bank account, and we live sustainably only by using its interest, not digging into our capital. If we do withdraw more capital, we must then find ways of investing more, to increase our capital. You can hear this language finally gaining much more traction today as politicians, managers and the public use the phrases natural and social capital, as well as the financial and manufactured capital, and recognise our dependencies on the natural environment.

As such, I fully support the holistic, interdisciplinary sentiments and recommendations of Purwanto et al. (2020) in their introduction to the first issue of the Indonesian Journal of Applied Environmental Studies (InJAST). I have promoted interdisciplinary approaches to solving complex environmental problems throughout my career and worked with other academics and practitioners to support the realisation of the societal and economic impact of their research. We have increasingly recognised research impact institutionally and financially, but one main weakness persists and that is the availability of academic journals for publishing such interdisciplinary work. This journal can offer such a space for researchers and encourage the recognition and promotion of evidence to policy and practice communications. Most of all, this journal can foster the culture and confidence to ask the right questions to support the development of evidence-based decision making in policy and operational activities. I have spent a lot of time working with researchers who are doing excellent research but not asking the best questions to help improve management and utilisation of natural resources. Providing a forum in which students and early career researchers can confidently explore the rough answers to the right questions rather than the precise answers to the wrong questions, to paraphrase John Tukey (1915-2000), would be a wonderful role for InJAST.

I am delighted to be asked to share my environmental experiences and perspectives in this guest editorial for the second issue of InJAST, reflecting for me a long association with Indonesia and Indonesian environmental managers, conservationists and foresters. I have worked around the world, especially in the tropics, firstly as part of scientific expeditions and then leading increasingly complex research and development programmes and institutions. Since returning to the UK, I have been involved in enhancing the quality and impact of scientific and interdisciplinary research and supporting the application and institutionalisation of the ecosystem approach and ecosystem services assessments. Here, I will focus on three major tropical environmental management programmes, two in Indonesia and one in Guyana, South America.

These were complemented by subsequent involvement in the UK Government's environmental management system. All reflect the evolution of environmental management and the emergence of the ecosystem approach, now being institutionalised slowly but surely around the world.

\section{ENVIRONMENTAL MANAGEMENT DEVELOPMENT IN INDONESIA}

Following scientific and exploratory expeditions particularly to Indonesia and Malaysia, I was privileged in the 1990s to become part of the long-term Environmental Management Development in Indonesia (EMDI) programme, run jointly by the Indonesian Ministry of State for Environment (Kementerian Lingkungan Hidup/KLH) and Dalhousie University, Canada (CIDA-funded). EMDI provided comprehensive cross-disciplinary and interdisciplinary frameworks to advance environmental management capabilities through institutional strengthening and human resource development at many scales, from village level through to central government, especially with the Environmental Impact Management Agency 
(Badan Pengendalian Dampak Lingkungan/BAPEDAL). This remarkably advanced and innovative programme involved the Indonesian Ministry and government agencies, NGOs, industrial and consulting firms, and several universities across the archipelago in co-producing a coherent range of really pioneering approaches to national environmental management:

1. Spatial planning and regional environmental management, especially applying, for the time, pioneering GIS-based resource evaluation systems.

2. Environmental impact assessment (EIA) guidance and application and, well ahead of its time globally, integrating social impact assessment into the comprehensive EIA system.

3. Establishment of pollution-related environmental quality standards, especially, and today very topical globally, air quality emissions standards.

4. Hazardous substance regulations, management and training.

5. Marine and coastal environmental management, producing guidelines for the sustainable development and conservation of sensitive coastal ecosystems such as coral reefs, sea grass beds, and mangroves, with an exemplar marine park management plan for the Taka Bone Rate atoll by KLH and the Forest Protection and Nature Conservation (Perlindungan Hutan dan Pelestarian Alam/PHPA) of the Ministry of Forestry. The pioneering assessment of the multiple benefits derived from mangroves (Ruitenbeek 1992) continues to be cited today, e.g., Rumahorbo et al. (2020).

6. Environmental management support systems, strengthening the Government environmental statistics programme, regional balance sheets and state of environment reporting, as well as a foundational library in KLH.

7. Enhanced environmental law capabilities, improving compliance with environmental regulations standards and requirements.

8. Macro-policy support for policy formulation and analysis to serve integrated and long-term planning needs, especially in being able to respond to priority and emerging issues. It included development of a national strategy for terrestrial biodiversity and work on natural resources and environmental accounting. The latter was designed to estimate stock and depletion of natural resources and develop polices to evaluate the management of the environment.

9. Training and publications programmes. Along with the development of a Ministry-based library, graduate fellowships were offered in environmental management to government civil servants, NGOs and university academics, and a series of books were produced and published.

The publication programme proved to be an exceptional aspect and one rarely emulated by even the most comprehensive of later support programmes. Based on the original Ecology of Sumatra (Whitten et al. 1984) and Ecology of Sulawesi (Whitten et al., 1987) lead-authored by the inspirational Tony Whitten (1953-2017), EMDI established the bilingual Ecology of Indonesia book series with four new volumes on the ecology of Java and Bali (Whitten et al., 1996), Kalimantan (MacKinnon et al., 1997), the Indonesian Seas (Tomascik et al., 1997a, b), and Nusa Tenggara and Maluku (Monk et al., 1997). The Ecology of Papua (Marshall and Beehler, 2007a, b) was funded later by $\mathrm{BP}$ and the Gordon and Betty Moore Foundation. In addition to normal academic literature sources, the EMDI authors and their teams made substantial efforts to retrieve the extensive grey literature relating to the regions from local government and universities, consultancies, and colonial archives. Copies of all literature cited were lodged with the relevant local universities' Centres for Environmental Studies, and the books themselves distributed throughout the appropriate regions. The comprehensiveness of the data gathered and analysed to form the evidence base for future conservation and development can be illustrated by a summary of the volume for which I was lead author, The Ecology of Nusa Tenggara and Maluku. We presented baseline data as of the 1990s on this complex region's geology, climate, soils, biodiversity, ecosystems, people, and marine and land use, and discussed these in a historical as well as a developmental context. We compared traditional laws and customs around natural resource management with emerging national environmental laws and provided guidelines for researchers on beneficial ecological and socio-economic research projects. Many of these projects are still needed, their results providing vital guidance to the future development of one of the most vulnerable areas of Indonesia. As I wrote at the time "The complexity and vulnerability of these islands mean that development and environment are inextricably linked. If this is not understood and acted upon, there is no possibility for the ecologically sustainable development of Nusa Tenggara and Maluku." Whilst The Ecology of Indonesia series is now out of print, the English language versions are available on Kindle and they remain a significant baseline source of information for Government, NGOs, developers, researchers and students on the ecosystems, natural resources, and human activity and development across Indonesia.

I have described the EMDI programme in considerable detail because it illustrates what I see as essential for the sustainable management of natural resources of any country, that holistic, cross-departmental recognition and assessment of 
complex challenges not solved by purely technological or regulatory approaches but by integrating historical, present and future socio-economic elements.

\section{LEUSER ECOSYSTEM}

My second example from my experiences in this emerging approach to the sustainable management of natural resources focusses on the Leuser Ecosystem on the island of Sumatra. Located across North Sumatra and Aceh provinces, Leuser is still one of the richest expanses of tropical rain forest between India and the Philippines. It stretches from the peaks of Mt Leuser at $3,400 \mathrm{~m}$ asl into the wooded interior and down to the lowland plains and beaches of the Indian Ocean, and includes nine rivers, three lakes, and over 185,000 hectares of carbon-rich peatlands. It was and still is a crucial source of clean drinking water and agricultural livelihoods for two to four million people. It covers more than two million hectares, encompassing the designated Gunung Leuser National Park (a UNESCO Man and Biosphere Reserve since 1981 and on the list of World Heritage in Danger since 2011), adjacent logging concessions, plantations, and protection forests. The Leuser Ecosystem was legally recognised in 1995 through a Ministry of Forestry Decree (No.227/KPTS-II/1995), and then by a Presidential Decree in 1998 (No.33/1998). Through the Regulation of Aceh's Governor in 2006 (No. 11/2006), the management of the Leuser Ecosystem in the Aceh region was, and still is, mandated by the Central Government of Indonesia to the Provincial Government of Aceh, with implementation on the ground being carried out by the Leuser Ecosystem Management Agency (Badan Pengelola Kawasan Ekosistem Leuser/BPKEL). Then, in 2008 the Government Regulation No. 26/2008 on the National Spatial Plan established the Ecosystem Leuser as a National Strategic Area, which is an area of national interest for the benefits of economic development and the environment.

During the 1980s and early 1990s, 6.7 million hectares, or $29 \%$, of Sumatra's forest cover disappeared, and the largest tract of undisturbed forest was around the Gunung Leuser National Park. In the mid-1990s, the Leuser Development Programme (LDP) started as a cooperative venture between the European Union and the Government of Indonesia. This Integrated Conservation and Development Programme was a ground-breaking experiment to support one of the newest and largest conservation areas in Indonesia under an undeveloped and novel managerial system - giving a conservation concession to an NGO, the Leuser International Foundation. The LDP was co-produced and executed in partnership with many government agencies and NGOs, the latter being involved especially in monitoring activities, research, microproject implementation, training programmes, and local community engagement. It was one of the first moves towards a landscape-planning and adaptive management approach to conservation planning (Wells et al., 1999) and championed wider application of spatial planning with the regional and local governments to avoid social and environmental problems, such as locating new builds on seasonally flooded land. The LDP has since been extensively analysed and reviewed, contributing lessons to the continuing sustainable management and utilisation approaches in the area and elsewhere (e.g., Monk and Purba, 1999; Monk, 2001; Kelman, 2013).

My role in the LDP was to co-lead the setting up and management of the research, monitoring, and information programme in partnership with Dr Zainal Abidin Pian from Syiah Kuala University in Banda Aceh. We highlighted research priorities, supported both pure and applied research of relevance to the management and conservation of the Leuser Ecosystem, and built up an extensive open-access environmental management library in Medan. Studies were undertaken by Indonesian researchers and students from several universities as well as by international researchers and consultants. Probably one of the most significant outputs was that of van Beukering et al. (2003, 2009), who provided the first total economic value (TEV) of the ecosystem services and benefits of any rain forest area, evaluating the economic consequences of deforestation versus conservation scenarios for the Leuser Ecosystem. Most innovatively and influentially, they explored the trade-off between short-term gains for some stakeholders versus larger long-term losses for others. It became an exemplar of innovative valuation of multiple benefits from natural resources as recognised by multiple stakeholders, from local communities to the global community (TEEB, 2009; Förster and Berghöfer, 2010; Brander and Eppin, 2015).

\section{IWOKRAMA}

The phrase 'one planet living' is being rapidly adopted around the world in the face of Covid-19 impacts. It was, however, the Brundtland Report (Brundtland, 1987) that introduced this phrase, articulating the increasing concerns of the times around unsustainable living, food security, and the 'greenhouse effect'. The Brundtland Report set the scene for the 1992 United Nations Conference on Environment and Development, also known as the Rio or Earth Summit, focussing a generation on sustainable living. By 1992, with more than half the world's tropical forests already converted to non-forest uses, a more equitable, sustainable approach particularly to rain forest management was urgently required. This approach was articulated through the United Nations (UN) Convention on Biological Diversity (CBD), opened at Rio and coming into force in 1993. The CBD was the first legal tool dedicated to promoting sustainable development by recognising that biological diversity is 
about more than plants, animals and microorganisms and their ecosystems. It was also about our dependency on the natural world for food security, medicines, fresh air and water, shelter, and a clean and healthy environment in which to live.

The CBD introduced the ecosystem approach and its related idea of ecosystem services assessments, which increasingly became the basis for natural resource management and a critically important tool to deliver sustainable development. What is rarely recognised, however, is that two years after the Brundtland Report appeared and two years before the Rio Summit and the CBD focussed the world, the then President of Guyana, Desmond Hoyte, had pledged one million acres (370,000 hectares) of rain forest to the international community as 'Guyana's gift to the world and a donation to the lungs of mankind", at the 1989 Commonwealth Heads of Government Meeting. It was to be used as an experimental centre to demonstrate whether or not rain forests could be conserved and sustainably used whilst making a significant contribution to both local and national economic development.

From its launch in 1996, the Iwokrama International Centre for Rain Forest Conservation and Development began to build up programmes of pluralistic partnerships at the local, national, regional and international levels. Local people were directly involved in all aspects, including compiling biodiversity inventories, planning management strategies, and training rangers. An exceptionally strong and focussed programme developed and supported representation systems for indigenous and local communities with clear connections and reliance on the area's natural resources. The UN provided initial funding, and by 2000 the Centre had become a multi-donor international programme. Iwokrama's donors were also then hoping that the Centre itself might become financially independent, using profits from experimental ecologically and economically sustainable eco-tourism, training programmes, and sale of timber and other forest products, in addition to contributing significantly to both local and national economic development. After I joined the Centre in mid-2001 as their Director General to start that business-focussed transition, a detailed economic analysis of this forest resource again clearly demonstrated that sustainable utilisation would generate twice the economic value of unsustainable utilisation (van Beukering and van Heeren, 2002; van Beukering, 2003). Once again, local communities would be the ones to benefit most from this process of sustainable utilisation through diverse activities such as fisheries, agriculture, tourism, non-timber forest products, and timber, with more global benefits and services such as biodiversity and carbon sequestration also benefiting regional and international communities. This emphasized the challenge of developing a vision for such large-scale management of natural resources that could be owned by all levels of stakeholders through an effective coordination and management body. The Centre continues to deliver clear field-based demonstrations of effectiveness of sustainable forest management and utilisation for both biodiversity and stakeholders and is widely recognised as an exemplar for co-management as the key workable option for successful natural resource management.

\section{GLOBAL PROGRAMMES AND LEGISLATION GHANGES $\mathrm{t}$}

Let's step back from these specific field examples and consider in more detail what was happening globally to embed sustainable development into society and politics. The start of the 21 st century saw the international community pay increasing attention to sustainable development and the sustainable management of natural resources through the application of the ecosystem approach and ecosystem services assessments. Political calls for actions to achieve sustainable development have been reinforced by increasing applied interdisciplinary assessments and development of tools. The functional links between biodiversity, health and human well-being were recognised through the eight UN Millennium Development Goals (MDGs) with targets for 2000-2015 to: eradicate extreme poverty and hunger; achieve universal primary education; promote gender equality and empower women; reduce child mortality; improve maternal health; combat HIV/AIDS, malaria, and other diseases; ensure environmental sustainability; and develop a global partnership for development. The associated 2001-2005 Millennium Ecosystem Assessment (MA) addressed the consequences of global changes of human well-being in ecosystems and provided a scientific basis for improving conservation and sustainable use of living resources through the first global survey of ecological services (MA, 2005). The global MA inspired the world's first national assessment: UK's National Ecosystem Assessment or NEA (UK National Ecosystem Assessment 2011, 2014). Other national assessments of various forms and shapes have followed, e.g., Schröter et al. (2016). Following the MA, several global initiatives emerged to develop scientifically based frameworks for the application of ecosystem services assessment into political and institutional decision making:

1. 2007: The Economics of Ecosystems and Biodiversity (TEEB) global initiative focusses on "making nature's values visible" and mainstreaming the values of biodiversity and ecosystem services into decision making at all levels.

2. 2010: The World Bank-led global partnership Wealth Accounting and the Valuation of Ecosystem Services (WAVES) aimed to ensure that natural 
resources were mainstreamed in development planning and national economic accounts. Indonesia joined WAVES as one of its core implementing countries in late 2013. WAVES is now part of the broader World Bank umbrella initiative, the Global Program for Sustainability (GPS).

3. 2012: The Intergovernmental Science-Policy Platform on Biodiversity and Ecosystem Services (IPBES) aims to improve the interface between science and policy on issues of biodiversity and ecosystem services.

As the MDG era ended in 2015, the UN launched the 2030 Agenda for Sustainable Development to be delivered through 17 Sustainable Development Goals (SDGs) over the next 15 years. The SDGs crystallise the global understanding that humans are intimately connected and dependent on our natural environment. Actions to end poverty and other deprivations are intimately connected with strategies that improve health and education, reduce inequality, spur economic growth, and tackle the climate emergency and biodiversity loss. Warnings continue to emerge especially from IPBES, e.g., their regional biodiversity assessments and the state of land degradation report (IPBES, 2018) demonstrated that damaged environments threaten the well-being of 3.2 billion people. Their first Global Biodiversity Assessment (IPBES, 2019a, b) provided the most comprehensive global official base of evidence for policy makers ever seen, reviewing approximately 15,000 scientific and government sources, alongside indigenous and local knowledge sources from around the world. The report's conclusions reconfirm the links between biodiversity loss and impacts to human societies in various areas critical for human survival.

\section{WELSH LEGISLATION}

A necessary family commitment had led to my return to the UK when much of this exciting global progress was being made. Working in the UK Government's environmental protection agency meant I was part of some of this, especially the UK's NEA. When I moved to Wales its devolved administration was preparing to become the first country in the world to embed sustainable development and the UN's SDGs into law, in the Well-being of Future Generations (Wales) Act 2015 (WBFG). This Act formed the keystone of a highly innovative framework of legislation that aimed to deliver sustainable development through integrated land, water, and air management underpinned by an ecosystem services approach: the Planning (Wales) Act 2015; and the Environment (Wales) Act 2016.

The WBFG strengthened existing governance arrangements for improving the well-being of Wales to ensure that present needs are met without compromising the ability of future generations to meet their own needs - embracing one planet living. It set ambitious and long-term goals for a prosperous, resilient, healthier, more equal Wales, of vibrant culture with cohesive communities, and which is globally responsible in its actions. Shared outcomes for Wales were articulated through seven Well-being Goals, to which the public services bodies listed within the Act should maximise their contribution when delivering their functions and activities. These Well-being Goals map clearly back to the international SDGs. The WBFG utilises these principles of sustainable development to define five ways of working that set out how decisions must be taken and actions delivered: considering the long term, being preventative, involving people, taking integrated decisions, and delivering collaboratively. Applying these five ways of working breaks down policy and operational silos and ensures an outcome focus to public service delivery that improves the well-being of Wales, socially, environmentally, economically and culturally.

Environmental management in Wales under this legislation has not surprisingly also taken an innovative route. It is undertaken by Natural Resources Wales (NRW), with whom I work. It is the largest Welsh Government Sponsored Body - employing 1,900 staff across Wales with an annual budget of UK £180 million - with the remit to deliver and coordinate the sustainable management and utilisation of the natural resources of Wales through the application of the ecosystem approach. It therefore quite logically but innovatively brings together the traditional environmental protection and regulation government agency with those for conservation and forestry. In Indonesia, this might be like amalgamating BAPEDAL with the field arms of several of the Ministry of Environment and Forestry Directorates General, e.g., Directorate General of Nature Resources and Ecosystem Conservation (Direktorat Fenderal Konservasi Sumber Daya Alam dan Ekosistem/KSDAE).

NRW is the first government organisation to operationalise an ecosystems approach formally. To do so has immense challenges for governments and communities that must embrace uncertainty, adaptive management, and co-production. Policy, practice and law in the field of nature and landscape are increasingly moving from a traditional regulatory approach of conservation and mitigation towards this dynamic, 'beyond-regulation' ecosystem approach, and draw on understanding and considering complex systems and making effective linkages between nature, place and society. The implications of this change are still to be recognised and tackled from institutional, theoretical and methodological perspectives. Understanding the ecological terms and applications of terms such as resilience, natural capital and ecosystem services, and the institutional and disciplinary challenges of adopting 
landscape-scale approaches and nature-based solutions continue (Cowling et al., 2008; Kirsop-Taylor and Hejnowicz, 2020; Kirsop-Taylor et al., 2020).

\section{INDONESIAN JOURNAL OF APPLIED ENVIRONMENTAL STUDIES}

Today, the complexity of our global, national and local challenges demands solutions from an ever-increasing juxtaposition of technological, scientific, social, political and economic disciplines. InJAST provides the expanding community of nationally produced environmental managers and researchers with a new platform on which to share the range of subjects and insights that can guide and drive the sustainable management and utilisation of Indonesia. Universities and academics have never before worked in such critical times as producers and promoters of knowledge, skills, and innovation, to raise awareness and understanding, develop or revisit frameworks, and offer solutions, be they short-term fixes or, more importantly, those long-term transformations.

We know that reconciling conservation and development has been notoriously difficult for several decades, and the pursuit of this has led at times to extremely polarised positions and contentious debate. But we do now have global and local frameworks, and the tools, to enable us to focus on trade-offs and synergies between conservation, utilisation, and development, capacity building, and co-production. This calls for considerable breadth of appreciation, understanding and interdisciplinarity. We can do this.

\section{REFERENCES}

Brundtland Commission (1987). Our Common Future. United Nations/Oxford University Press.

Brander, L. and F. Eppin (2015). The Economics of Ecosystems and Biodiversity for Southeast Asia. ASEAN TEEB Scoping Study. TEEB.

Cowling, R.M., B. Egoh, A.T. Knight, P. J. O'Farrell, B. Reyers, M. Rouget, D. J. Roux, A. Welz, and A. Wilhelm-Rechman (2008). An operational model for mainstreaming ecosystem services for implementation. PNAS 105 (28) 9483-9488.

Förster, J. and A. Berghöfer (2010). TEEBcase forest valuation stimulates green development policies in the Province of Aceh, Indonesia, based on van Beukering et al. (2003 and 2008). TEEB.

IPBES (2018). The IPBES assessment report on land degradation and restoration. Montanarella, L., Scholes, R., and Brainich, A. (eds.). Secretariat of the Intergovernmental Science-Policy Platform on Biodiversity and Ecosystem Services, Bonn, Germany. 744 pages. https://doi.org/10.5281/zenodo.3237392
IPBES (2019a). Summary for policymakers of the global assessment report on biodiversity and ecosystem services of the Intergovernmental Science-Policy Platform on Biodiversity and Ecosystem Services. S. Díaz, J. Settele, E.S. Brondízio, H.T. Ngo, M. Guèze, J. Agard, A. Arneth, P. Balvanera, K.A. Brauman, S.H.M. Butchart, K.M.A. Chan, L.A. Garibaldi, K. Ichii, J. Liu, S.M. Subramanian, G.F. Midgley, P. Miloslavich, Z. Molnár, D. Obura, A. Pfaff, S. Polasky, A. Purvis, J. Razzaque, B. Reyers, R. Roy Chowdhury, Y.J. Shin, I.J. Visseren-Hamakers, K.J. Willis, and C.N. Zayas (eds). Bonn, Germany: IPBES Secretariat. https://doi.org/10.5281/zenodo.3553579t

IPBES (2019b). Global assessment report on biodiversity and ecosystem services of the Intergovernmental Science-Policy Platform on Biodiversity and Ecosystem Services. E.S. Brondizio, J. Settele, S. Díaz, and H.T. Ngo (eds). Bonn, Germany: IPBES secretariat.

Kelman, C.C. (2013). Governance lessons from two Sumatran integrated conservation and development projects. Conservation and Society 11(3): 247-263.

Kirsop-Taylor N.A. and A. Hejnowicz (2020). Designing adhocratic public agencies for 21st century nexus complexity: the case of Natural Resources Wales. Public Policy and Administration. https://doi.org/10.1177/0952076720921444

Kirsop-Taylor, N.A., A.P. Hejnowicz and K. Scott (2020). Four Cultural Narratives for Managing Social-ecological Complexity in Public Natural Resource Management. Environmental Management. https://doi.org/10.1007/s00267-020-01320-6

MA (2005). Living Beyond Our Means: Natural Assets and Human Well-being. Statement of the MA Board. Millennium Ecosystem Assessment.

MacKinnon, K., G. Hatta, H. Halim and A. Mangalik (1997). The Ecology of Kalimantan. The Ecology of Indonesia Series Volume III. Singapore: Periplus Editions (HK) Ltd.

Marshall, A.J. and B.M. Beehler (2007a). Ecology of Indonesian Papua Part One. The Ecology of Indonesia Series Volume VI. Singapore: Periplus Editions (HK) Ltd.

Marshall, A.J. and B.M. Beehler (2007b). Ecology of Indonesian Papua Part Two. The Ecology of Indonesia Series Volume VI. Singapore: Periplus Editions (HK) Ltd.

Monk, K.A. (2001). The evolution and scope of ICDPs: the example of the Leuser Ecosystem, Sumatra, Indonesia. Parks 11(2): 33-40.

Monk, K.A. and D. Purba (1999). Progress towards collaborative management of the Leuser Ecosystem, Sumatra, Indonesia. Proceedings of the 2nd Regional Forum for South-East Asia of the IUCN World Commission for Protected Areas, Pakse, Lao PDR, Volume 3. 
Monk, K.A., Y. de Fretes and G. Reksodiharjo-Lilley (1997). The Ecology of Nusa Tenggara and Maluku. The Ecology of Indonesia Series Volume V. Singapore: Periplus Editions (HK) Ltd.

Purwanto, Y., E. Sukara, P.S. Ajiningrum and D. Priatna (2020). Cultural diversity and biodiversity as foundation of sustainable development. Indonesian Fournal of Applied Environmental Sciences 1(1): 2-10.

Ruitenbeek, J. (1992). Mangrove management: an economic analysis of management options with a focus on Bintuni Bay. EMDI Environmental Reports 8: Irian Jaya. Halifax, Nova Scotia: Dalhousie University, EMDI Project.

Rumahorbo, T. Basa, B. Hamuna and H. J. Keiluhu (2020). An assessment of the coastal ecosystem services of Jayapura City, Papua Province, Indonesia. Environmental Eீ Socio-economic Studies 8: 45-53.

Schröter, M., C. Albert, A. Marques, W. Tobon, S. Lavorel, J. Maes, C. Brown, S. Klotz and A. Bonn (2016). National Ecosystem Assessments in Europe: A Review. BioScience 66(10): 813-828.

TEEB (2009). The Economics of Ecosystems and Biodiversity for National and International Policy Makers Summary: Responding to the Value of Nature.

Tomascik, T., A.J. Mah, A. Nontji and M.K. Moosa (1997a). The Ecology of the Indonesian Seas Part 1. The Ecology of Indonesia Series Volume VIII. Singapore: Periplus Editions (HK) Ltd.

Tomascik, T., A.J. Mah, A. Nontji and M.K. Moosa (1997a). The Ecology of the Indonesian Seas Part 1. The Ecology of Indonesia Series Volume VIII. Singapore: Periplus Editions (HK) Ltd.

Tomascik, T., A.J. Mah, A. Nontji and M.K. Moosa (1997b). The Ecology of the Indonesian Seas Part 2. The Ecology of Indonesia Series Volume VIII. Singapore: Periplus Editions (HK) Ltd.
UK National Ecosystem Assessment (2011). The UK National Ecosystem Assessment: Synthesis of the Key Findings. Cambridge, UK: UNEP-WCMC.

UK National Ecosystem Assessment (2014). The UK National Ecosystem Assessment: Synthesis of the Key Findings. Cambridge, UK: UNEP-WCMC and LWEC.

van Beukering, P.J.H. (2003). The economic value of tropical forest: A comparison between the Leuser National Park (Indonesia) and the Iwokrama Forest (Guyana). In P.A. Zuidema (ed.), Tropical forests in multi-functional landscapes. Seminar proceedings. Prince Bernhard Centre, University, Utrecht. (pp. 23-32).

van Beukering, P.J.H. and A.E. van Heeren (2002). The economic value of the Iwokrama Forest Reserve, Guyana: a stakeholder perspective. IVM Report No. W-02/22. Amsterdam: Department of Economics and Technology.

van Beukering, P., H. Cesar and M. Janssen (2003). Economic valuation of the Leuser National Park on Sumatra, Indonesia. Ecological Economics 44: 43-62.

van Beukering, P.J.H., K. Grogan, S.L. Hansfort and D. Seager (2009). An economic valuation of Aceh's forests: The road towards sustainable development. IVM Report No. R-09/14. Amsterdam: Institute for Environmental Studies.

Wells, M., S. Guggenheim, A. Khan, W. Wardojo and P. Jepson (1999). Investing in biodiversity: a review of Indonesia's integrated conservation and development projects. Washington, DC: The World Bank.

Whitten, A.J., S.J. Damanik and J. Anwar (1984). The Ecology of Sumatra. Gadjah Mada University Press.

Whitten, A.J., M. Mustafa and G.S. Henderson (1987). The Ecology of Sulawesi. Gadjah Mada University Press.

Whitten, A.J., R.E. Soeriaatmadja and S.A. Afiff (1996). The Ecology of Java and Bali. The Ecology of Indonesia Series Volume III. Singapore: Periplus Editions (HK) Ltd. 